\title{
PERMANENT GENETIC RESOURCES NOTE Permanent Genetic Resources added to Molecular Ecology Resources Database 1 February 2012 - 31 March 2012
}

\author{
Molecular Ecology Resources Primer Development Consortium, ${ }^{1}$ Malvina Andris, ${ }^{2}$ M. C. ARias, ${ }^{3}$ \\ BRANDON L. BARTHEL, ${ }^{4}$ BURTON H. BLUHM, ${ }^{5}$ JOËL BRIED,${ }^{2}$ D. CANAL,${ }^{6}$ X. M. CHEN,${ }^{7,8}$ P. \\ CHENG,${ }^{7}$ MARINA B. CHIAPPERO,${ }^{9}$ MANUELA M. COELHO, ${ }^{10}$ ANGELA B. COLLINS, ${ }^{4} \mathrm{M} . \mathrm{DASH},{ }^{11}$ \\ MICHELlE C. DAVIS, ${ }^{4}$ MARGARIDA DUARTE,${ }^{10}$ MARIE-PIERRE DUBOIS, ${ }^{12}$ E. FRANÇOSO, ${ }^{3} \mathrm{M}$. A. \\ GALMES, ${ }^{13,14}$ KESHNI GOPAL,${ }^{15,16}$ PHILIPPE JARNE, ${ }^{12}$ MARTIN KALBE, ${ }^{17}$ LESZEK KARCZMARSKI, ${ }^{18}$ \\ HUN KIM, ${ }^{5}$ MÓNICA B. MARTELLA, ${ }^{19}$ RICHARD S. MCBRIDE, ${ }^{20}$ VALERIA NEGRI, ${ }^{21}$ J. J. NEGRO, ${ }^{6}$ ANNAKAY D.

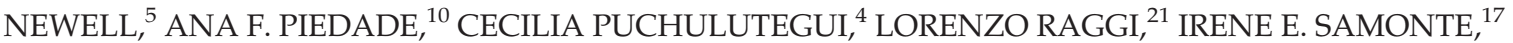 \\ J. H. SARASOLA,${ }^{13,22,14}$ D. R. SEE ${ }^{8}$ SEIFU SEYOUM, ${ }^{4}$ MÓNICA C. SILVA, ${ }^{10}$ C. SOLARO,${ }^{13,22}$ KRYSTAL A. TOLLEY, ${ }^{16}$ \\ MICHAEL D. TRINGALI, ${ }^{4}$ A. VASEMÄGI, ${ }^{11,23}$ L. S. XU ${ }^{7}$ and J. I. ZANÓN-MARTÍNEZ ${ }^{13,22}$ \\ ${ }^{1}$ Molecular Ecology Resources Editorial Office, 6270 University Blvd, Vancouver, BC V6T 1Z4, Canada, ${ }^{2}$ Departamento de \\ Oceanografia e Pescas, Centro do IMAR da Universidade dos Acores, 9901-862 Horta, Açores, Portugal, ${ }^{3}$ Departamento de Genética \\ e Biologia Evolutiva, Instituto de Biociências, Universidade de São Paulo, rua do Matão, 277, São Paulo, SP 05508-090, Brazil, \\ ${ }^{4}$ Florida Fish and Wildife Conservation Commission, 100 Eighth Avenue S.E. Saint Petersburg, FL 33701-5095, USA, ${ }^{5}$ Department \\ of Plant Pathology, University of Arkansas, Fayetteville, AR 72701, USA, ${ }^{6}$ Department of Evolutionary Ecology, Estación Biológica \\ de Doñana-CSIC, Avda. Américo Vespucio s/n, 41092 Seville, Spain, ${ }^{7}$ Department of Plant Pathology, Washington State \\ University, Pullman, WA 99164-6430, USA, ${ }^{8}$ USDA-ARS, Wheat Genetics, Quality, Physiology, and Disease Research Unit, \\ Pullman, WA 99164-6430, USA, ${ }^{9}$ Consejo Nacional de Investigaciones Cientrifificas y Técnicas (CONICET) and Cátedra de \\ Genética de Poblaciones y Evolución, Facultad de Ciencias Exactas, Físicas y Naturales, Universidad Nacional de Córdoba, Av. Velez \\ Sarsfifield 299 (5000) Córdoba, Argentina, ${ }^{10}$ Centro de Biologia Ambiental, Faculdade de Ciências, Universidade de Lisboa, Campo \\ Grande, 1749-016 Lisboa, Portugal, ${ }^{11}$ Division of Genetics and Physiology, Department of Biology, University of Turku, 20014 \\ Turku, Finland, ${ }^{12}$ CEFE, UMR 5175 CNRS, 1919 route de Mende, 34293 Montpellier Cedex 5, France, ${ }^{13}$ Centro para el Estudio y \\ Conservación de las Aves Rapaces en Argentina (CECARA), Universidad Nacional de La Pampa, Avda. Uruguay 151, 6300 Santa \\ Rosa, La Pampa, Argentina, ${ }^{14}$ The Peregrine Fund, 5668 West Flying Hawk Lane, Boise, ID 83709, USA, ${ }^{15}$ Mammal Research \\ Institute, University of Pretoria, PO Box 61, Cape Town 8000, South Africa, ${ }^{16}$ Applied Biodiversity Research, South African \\ National Biodiversity Institute, Private Bag X7, Claremont, 7735 Cape Town, South Africa, ${ }^{17}$ Department of Evolutionary Ecology, \\ Max-Planck Institute for Evolutionary Biology, August-Thienemann Strasse 2, 24306 Ploen, Germany, ${ }^{18}$ The Swire Institute of \\ Marine Science, School of Biological Sciences, The University of Hong Kong, Cape d'Aguilar, Shek O, Hong Kong, ${ }^{19}$ Consejo \\ Nacional de Investigaciones Científificas y Técnicas (CONICET) and Centro de Zoología Aplicada, Facultad de Ciencias Exactas, \\ Físicas y Naturales, Universidad Nacional de Córdoba, Rondeau 798 (5000) Córdoba, Argentina, ${ }^{20}$ National Marine Fisheries \\ Service, Northeast Fisheries Science Center, 166 Water Street, Woods Hole, MA 02543-1026, USA, ${ }^{21}$ Department of Applied \\ Biology, University of Perugia, Borgo XX Giugno 74, 06121 Perugia, Italy, ${ }^{22}$ Instituto de las Ciencias de la Tierra y Ambientales de \\ La Pampa (INCITAP), Consejo Nacional de Investigaciones Científicas y Técnicas de Argentina (CONICET), Avda. Uruguay 151, \\ 6300 Santa Rosa, La Pampa, Argentina, ${ }^{23}$ Department of Aquaculture, Institute of Veterinary Medicine and Animal Science, \\ Estonian University of Life Sciences, 51014 Tartu, Estonia
}

\begin{abstract}
This article documents the addition of 171 microsatellite marker loci and 27 pairs of single nucleotide polymorphism (SNP) sequencing primers to the Molecular Ecology Resources Database. Loci were developed for the following species: Bombus pauloensis, Cephalorhynchus heavisidii, Cercospora sojina, Harpyhaliaetus coronatus, Hordeum vulgare, Lachnolaimus maximus, Oceanodroma monteiroi, Puccinia striiformis f. sp. tritici, Rhea americana, Salmo salar, Salmo trutta, Schistocephalus solidus, Sousa plumbea and Tursiops aduncus. These loci were cross-tested on the following species: Aquila heliaca, Bulweria bulwerii, Buteo buteo, Buteo swainsoni, Falco rusticolus, Haliaeetus albicilla, Halobaena caerulea, Hieraaetus fasciatus, Oceanodroma castro, Puccinia graminis f. sp. Tritici, Puccinia triticina, Rhea pennata and Schistocephalus pungitii. This article also documents the addition of 27 sequencing primer pairs for Puffinus baroli and Bulweria bulwerii and cross-testing
\end{abstract}

Correspondence: Molecular Ecology Resources Primer Development Consortium, E-mail: editorial.office@molecol.com 
of these loci in Oceanodroma castro, Pelagodroma marina, Pelecanoides georgicus, Pelecanoides urinatrix, Thalassarche chrysostoma and Thalassarche melanophrys.

This article documents the addition of 171 microsatellite marker loci and 27 pairs of single nucleotide polymorphism (SNP) genotyping primers to the Molecular Ecol- ogy Resources Database. Table 1 contains information on the focal species, the number of loci developed, any other species the loci were tested in and the accession numbers

Table 1 Information on the focal species, the number of loci developed, any other species the loci were tested in and the accession numbers for the loci in both the Molecular Ecology Resources Database and GenBank. The authors responsible for each set of loci are listed in the final column

\begin{tabular}{|c|c|c|c|c|c|}
\hline Species & $\begin{array}{l}\text { No. primers } \\
\text { developed }\end{array}$ & $\begin{array}{l}\text { Other species } \\
\text { tested }\end{array}$ & $\begin{array}{l}\text { MER database } \\
\text { no. }\end{array}$ & $\begin{array}{l}\text { GenBank } \\
\text { accession no. }\end{array}$ & Authors \\
\hline Bombus pauloensis & 12 & $\mathrm{n} / \mathrm{a}$ & $48673-48684$ & JN997460-JN997471 & $\begin{array}{l}\text { Françoso, E.; } \\
\text { Arias, M.C. }\end{array}$ \\
\hline $\begin{array}{l}\text { Cephalorhynchus heavisidii, } \\
\text { Sousa plumbea and } \\
\text { Tursiops aduncus }\end{array}$ & 16 & $\mathrm{n} / \mathrm{a}$ & $\begin{array}{l}48724-48728 \\
48730-48763\end{array}$ & See article for details & $\begin{array}{l}\text { Gopal, Keshni; } \\
\text { Tolley, Krystal A.; } \\
\text { Karczmarski, Leszek }\end{array}$ \\
\hline Cercospora sojina & 8 & $\mathrm{n} / \mathrm{a}$ & $48716-48723$ & JQ624627-JQ624634 & $\begin{array}{l}\text { Kim, Hun; } \\
\text { Newell, Annakay D.; } \\
\text { Bluhm, Burton H. }\end{array}$ \\
\hline Harpyhaliaetus coronatus & 17 & $\begin{array}{l}\text { Aquila heliaca, } \\
\text { Buteo buteo, } \\
\text { Buteo swainsoni, } \\
\text { Falco rusticolus, } \\
\text { Haliaeetus albicilla, } \\
\text { Hieraaetus fasciatus }\end{array}$ & $\begin{array}{l}48793-48798 \\
48800-48810\end{array}$ & $\begin{array}{l}\text { JQ309945-JQ309948, } \\
\text { JQ309950-JQ309961, } \\
\text { JQ321581 }\end{array}$ & $\begin{array}{l}\text { Sarasola, J. H.; } \\
\text { Canal, D.; } \\
\text { Solaro, C.; } \\
\text { Galmes, M. A.; } \\
\text { Zanón-Martínez, J. I.; } \\
\text { Negro, J. J. }\end{array}$ \\
\hline Hordeum vulgare & 10 & $\mathrm{n} / \mathrm{a}$ & $48783-48792$ & $\begin{array}{l}\text { AF043090, AY008692, } \\
\text { AY156992, AY785849, } \\
\text { AY785885, DQ297407, } \\
\text { DQ539338, EU331872, } \\
\text { X99973 }\end{array}$ & $\begin{array}{l}\text { Raggi, Lorenzo; } \\
\text { Negri, Valeria }\end{array}$ \\
\hline Lachnolaimus maximus & 29 & $\mathrm{n} / \mathrm{a}$ & $\begin{array}{l}48940-48967, \\
48983\end{array}$ & $\begin{array}{l}\text { FJ844445-FJ844456, } \\
\text { FJ844458-FJ844474 }\end{array}$ & $\begin{array}{l}\text { Seyoum, Seifu; } \\
\text { Tringali, Michael D.; } \\
\text { Barthel, Brandon L.; } \\
\text { Puchulutegui, Cecilia; } \\
\text { Davis, Michelle C.; } \\
\text { Collins, Angela B.; } \\
\text { Mcbride, Richard S. }\end{array}$ \\
\hline Oceanodroma monteiroi & 18 & $\begin{array}{l}\text { Bulweria bulwerii, } \\
\text { Halobaena caerulea, } \\
\text { Oceanodroma castro }\end{array}$ & $48764-48781$ & JQ303226-JQ303243 & $\begin{array}{l}\text { Bried, Joël; } \\
\text { Andris, Malvina; } \\
\text { Dubois, Marie-Pierre; } \\
\text { Jarne, Philippe }\end{array}$ \\
\hline $\begin{array}{l}\text { Puccinia striiformis } \\
\text { f. sp. tritici }\end{array}$ & 17 & $\begin{array}{l}\text { Puccinia graminis } \\
\text { f. sp. Tritici, } \\
\text { Puccinia triticina }\end{array}$ & $48906-48922$ & $\begin{array}{l}\text { EG374292.1, GH737707.1, } \\
\text { GH737337.1, GH737942.1, } \\
\text { GH737347.1, GH737353.1, } \\
\text { GH737872.1, GH737984.1, } \\
\text { GH737893.1, JK479800, } \\
\text { JK479801, JK479803, } \\
\text { JK479804, JK479808, } \\
\text { JK479809, JK479813 }\end{array}$ & $\begin{array}{l}\text { Cheng, P.; } \\
\text { Chen, X. M.; } \\
\text { Xu, L. S.; } \\
\text { See, D. R. }\end{array}$ \\
\hline Rhea americana & 8 & Rhea pennata & $48685-48692$ & JQ067657-JQ067664 & $\begin{array}{l}\text { Chiappero, Marina B.; } \\
\text { Martella, Mónica B. }\end{array}$ \\
\hline $\begin{array}{l}\text { Salmo salar and } \\
\text { Salmo trutta }\end{array}$ & 22 & $\mathrm{n} / \mathrm{a}$ & $\begin{array}{l}48923-48939 \\
48968-48982\end{array}$ & $\begin{array}{l}\text { EF427381, EF210363, } \\
\text { EU008541, } \\
\text { FJ969488-FJ969490, } \\
\text { GQ505858-GQ505860 }\end{array}$ & $\begin{array}{l}\text { Dash, M.; } \\
\text { Vasemägi, A. }\end{array}$ \\
\hline $\begin{array}{l}\text { Schistocephalus } \\
\text { solidus }\end{array}$ & 14 & $\begin{array}{l}\text { Schistocephalus } \\
\text { pungitii }\end{array}$ & $48811-48824$ & JQ619705-JQ619718 & $\begin{array}{l}\text { Samonte, Irene E.; } \\
\text { Kalbe, Martin }\end{array}$ \\
\hline
\end{tabular}


Table 2 Information on the focal species, the sequencing primer pairs developed, the number of single nucleotide polymorphisms observed and any other species the loci were tested in. The next columns contain the number of allele-specific primers and probes developed, and the Molecular Ecology Resources Database and GenBank accession numbers, respectively. The authors responsible for each set of loci are listed in the final column

\begin{tabular}{|c|c|c|c|c|c|c|c|c|}
\hline Species & $\begin{array}{l}\text { No. } \\
\text { primer } \\
\text { pairs }\end{array}$ & $\begin{array}{l}\text { No. SNPs in } \\
\text { sequence }\end{array}$ & Other species tested & $\begin{array}{l}\text { No. allele } \\
\text { specific } \\
\text { primers/ } \\
\text { probe }\end{array}$ & $\begin{array}{l}\text { Target } \\
\text { gene(s) }\end{array}$ & $\begin{array}{l}\text { MER } \\
\text { database } \\
\text { numbers }\end{array}$ & $\begin{array}{l}\text { GenBank } \\
\text { accession no }\end{array}$ & Authors \\
\hline $\begin{array}{l}\text { Bulweria } \\
\text { bulwerii and } \\
\text { Puffinus baroli }\end{array}$ & 27 & 123 & $\begin{array}{l}\text { Oceanodroma castro, } \\
\text { Pelagodroma marina, } \\
\text { Pelecanoides georgicus, } \\
\text { Pelecanoides urinatrix, } \\
\text { Thalassarche chrysostoma, } \\
\text { Thalassarche melanophrys }\end{array}$ & $\mathrm{n} / \mathrm{a}$ & $\mathrm{n} / \mathrm{a}$ & $48693-48715$ & $\begin{array}{l}\text { JS799780- } \\
\text { JS799802 }\end{array}$ & $\begin{array}{l}\text { Silva, Mónica C.; } \\
\text { Duarte, Margarida; } \\
\text { Piedade, Ana F.; } \\
\text { Coelho, M. Manuela }\end{array}$ \\
\hline
\end{tabular}

for the loci in both the Molecular Ecology Resources Database and GenBank. The authors responsible for each set of loci are listed in the final column. Table 2 presents information on SNP genotyping resources added to the MER database and presents data on the focal species, the number of sequencing primer pairs, the observed number of SNPs, other species the loci were tested in and the number of allele-specific primers or probes. The MER database and GenBank accession numbers and the authors responsible are also listed. A full description of the development protocol for the loci presented here can be found on the Molecular Ecology Resources Database (http://tomato.biol.trinity.edu/). 